\title{
Importance of casein micelle size and milk composition for milk gelation
}

\author{
M. Glantz, ${ }^{* 1}$ T. G. Devold,† G. E. Vegarud,† H. Lindmark Månsson,ł H. Stålhammar,§ and M. Paulsson* \\ ${ }^{*}$ Department of Food Technology, Engineering and Nutrition, Lund University, PO Box 124, SE-221 00 Lund, Sweden \\ †Department of Chemistry, Biotechnology and Food Science, Norwegian University of Life Sciences, PO Box 5003, NO-1432 Aas, Norway \\ ¥Swedish Dairy Association, Ideon Science Park, SE-223 70 Lund, Sweden \\ §VikingGenetics, PO Box 64, SE-532 21 Skara, Sweden
}

\section{ABSTRACT}

The economic output of the dairy industry is to a great extent dependent on the processing of milk into other milk-based products such as cheese. The yield and quality of cheese are dependent on both the composition and technological properties of milk. The objective of this study was to evaluate the importance and effects of casein $(\mathrm{CN})$ micelle size and milk composition on milk gelation characteristics in order to evaluate the possibilities for enhancing gelation properties through breeding. Milk was collected on 4 sampling occasions at the farm level in winter and summer from dairy cows with high genetic merit, classified as elite dairy cows, of the Swedish Red and Swedish Holstein breeds. Comparisons were made with milk from a Swedish Red herd, a Swedish Holstein herd, and a Swedish dairy processor. Properties of CN micelles, such as their native and rennet-induced CN micelle size and their $\zeta$-potential, were analyzed by photon correlation spectroscopy, and rennet-induced gelation characteristics, including gel strength, gelation time, and frequency sweeps, were determined. Milk parameters of the protein, lipid, and carbohydrate profiles as well as minerals were used to obtain correlations with native $\mathrm{CN}$ micelle size and gelation characteristics. Milk $\mathrm{pH}$ and protein, $\mathrm{CN}$, and lactose contents were found to affect milk gelation. Smaller native CN micelles were shown to form stronger gels when poorly coagulating milk was excluded from the correlation analysis. In addition, milk $\mathrm{pH}$ correlated positively, whereas $\mathrm{Mg}$ and $\mathrm{K}$ correlated negatively with native $\mathrm{CN}$ micellar size. The milk from the elite dairy cows was shown to have good gelation characteristics. Furthermore, genetic progress in relation to $\mathrm{CN}$ micelle size was found for these cows as a correlated response to selection for the Swedish breeding objective if optimizing for milk gelation characteristics. The results indicate that selection for smaller native $\mathrm{CN}$ micelles and lower milk $\mathrm{pH}$ through breeding would enhance

Received October 27, 2009.

Accepted December 8, 2009.

${ }^{1}$ Corresponding author: maria.glantz@food.lth.se gelation properties and may thus improve the initial step in the processing of cheese.

Key words: casein micelle size, milk gelation, milk composition, elite dairy cow

\section{INTRODUCTION}

The proportion of milk produced that is processed into other milk-based products has increased worldwide during recent decades (International Dairy Federation, 2008). The composition of the milk is crucial for the processability and quality of these products (Lucey and Singh, 1998; Amenu and Deeth, 2007) and thus the economic output of the dairy industry. Although animal breeding is a useful tool for optimizing milk processing properties, milk composition traits considered in the breeding objectives are still limited (Interbull, 2009).

Over the years, great interest has been taken in the CN micelles, mainly because of their industrial importance (Fox and Brodkorb, 2008). Their structure is essential in the processing of milk into gelled products such as cheese and yogurt (Horne, 1998; Tuinier and de Kruif, 2002), and their stability during heating, freezing, and drying make them valuable in different applications (de Kruif, 1999; Fox and Brodkorb, 2008). Despite the vast amount of research on the $\mathrm{CN}$ micelles, their detailed structure is still not fully known even though several models have been proposed (Horne, 1998; Walstra, 1999; Holt et al., 2003; Dalgleish et al., 2004). The broad conclusion is that $\mathrm{CN}$ micelles are polydisperse, colloidal, roughly spherical particles ranging from 50 to $600 \mathrm{~nm}$ in diameter, with an average diameter of around 200 nm (de Kruif, 1998; Holt et al., 2003; Fox and Brodkorb, 2008). The CN micelles are further characterized by $\kappa-\mathrm{CN}$ located at the surface, which gives the $\mathrm{CN}$ micelles a net negative charge and sterically stabilizes the micelles against flocculation (Dalgleish, 1998; Walstra, 1999; Tuinier and de Kruif, 2002). The size of the micelles has shown to vary between feeding regimens and individual cows (Devold et al., 2000), but also between season, with smaller CN micelles in summer compared with in winter (Holt and Baird, 1978; Holt and Muir, 1978). However, numerous studies also 
indicate great influence of milk composition on micellar size. It has been shown that the contents of $\mathrm{CN}$ and whey proteins affect the size of CN micelles (Devold et al., 2000), whereas the micellar size has been shown to be independent of the contents of $\mathrm{Ca}$ and inorganic phosphate (Dalgleish et al., 1989). Furthermore, CN micelle size is influenced by genetic variants of proteins, most of all by the content of $\kappa$-CN (Lodes et al., 1996; Walsh et al., 1998; Devold et al., 2000).

In Sweden, 35\% of the milk produced today is used to make cheese (Swedish Dairy Association, 2008). In the processing of cheese, the initial stage involves enzymatic hydrolysis of $\kappa$ - $\mathrm{CN}$ by rennet. This reduces the steric repulsion and net negative charge between the $\mathrm{CN}$ particles, thus making the $\mathrm{CN}$ micelles susceptible to aggregation, and a curd starts to form (Dalgleish, 1992; Lucey, 2002; Lucey et al., 2003). The quality of the curd formed is dependent on the physical and chemical properties of the $\mathrm{CN}$ micelles, of which the micellar size is of great importance (Amenu and Deeth, 2007). It has been shown that smaller micelles form a more compact and hence firmer gel network than larger micelles (Niki and Arima, 1984; Ford and Grandison, 1986), whereas contradictory results have been obtained for rennet clotting time (Ekstrand et al., 1980; Dalgleish et al., 1981). Nevertheless, other factors, including the protein, $\mathrm{CN}$, and $\mathrm{Ca}$ contents, $\mathrm{pH}$, and the ratio of $\mathrm{CN}$ to whey proteins, have also been shown to influence gelation characteristics and to play an important role in the processing of cheese (Lucey et al., 2003; Auldist et al., 2004; Amenu and Deeth, 2007). Even so, only milk, fat, and protein yields are included in the Nordic breeding objectives regarding milk production. The weights of the 3 components are selected to ensure an increase in both protein and fat contents (VikingGenetics, 2008). In an earlier study, Glantz et al. (2009) showed that breeding programs considerably influence milk composition, yield of milk components, and processability, offering possibilities for altering the quality and stability of milk and dairy products through breeding. It could thus be an economical advantage to the dairy industry if more traits on milk quality are considered in the breeding objective. The aim of this study was to evaluate the importance and effects of CN micelle size and milk composition on milk gelation characteristics in order to evaluate the possibilities for optimizing the initial step in the processing of cheese through breeding.

\section{MATERIALS AND METHODS}

\section{Milk Samples}

Milk samples were collected twice, 1 wk apart, on the farm level in the winter and summer of 2007 as described by Glantz et al. (2009). Samples were obtained from the bovine research farm Nötcenter Viken (research herd; 304 and 300 cows on 2 occasions in winter, and 293 and 297 cows on 2 occasions in summer) in Falköping, Sweden, where an integral part of the Swedish breeding occurs. The herd consists of cows with high genetic merit, classified as elite dairy cows, of the Swedish Red (SR) and the Swedish Holstein (SH) breeds, which are the 2 most common breeds of dairy cattle in Sweden. The yields of milk, lipids, and proteins per cow at Nötcenter Viken are 31, 19, and 35\% higher, respectively, than the average yield per cow for farms in Sweden, which contribute to their high genetic merit. Thus, the elite cows reflect the expected genetic merit of the future Swedish cow population.

For comparison, milk was collected on the 4 occasions from 2 herds in the same geographical area: an SR farm (SR herd; 53 and 50 cows in winter, and 51 and 52 cows in summer) and an $\mathrm{SH}$ farm ( $\mathrm{SH}$ herd; 108 and 110 cows in winter, and 104 and 104 cows in summer). Bulk milk from the local dairy company was used as a reference (reference milk). In addition, milk was sampled from the respective breeds at Nötcenter Viken during the summer (research herd SR and research herd SH; 145 and 147 SR cows, and 148 and 150 SH cows, respectively).

\section{Size of Native and Rennet-Induced CN Micelles}

The Z-average hydrodynamic diameter of $\mathrm{CN}$ micelles were determined according to Devold et al. (2000) by photon correlation spectroscopy on skim milks diluted in simulated milk ultrafiltrate (SMUF; Jenness and Koops, 1962). The samples were defatted by centrifugation at $2,000 \times g$ for $30 \mathrm{~min}$ and subsequent removal of the fat layer. The measurements on both native and rennet-induced $\mathrm{CN}$ micelle size were performed using a ZetaSizer $3000 \mathrm{HS}$ apparatus (Malvern Instruments Ltd., Malvern, UK) equipped with a He-Ne laser $(632.8 \mathrm{~nm})$. The diluted samples were filtered through a $0.45-\mu \mathrm{m}$ filter (Pall Corporation, Port Washington, NY) before measurement and each sample was run in triplicate. Native CN micelle sizes were determined at $25^{\circ} \mathrm{C}$.

To obtain rennet-induced $\mathrm{CN}$ micelles, $10 \mathrm{~mL}$ of skim milk was preheated to $32^{\circ} \mathrm{C}$ in a water bath followed by the addition of chymosin $(0.90 \mathrm{~mL} / \mathrm{L}$ of Chy-Max Plus, 200 international milk clotting units/ mL, Christian Hansen A/S, Hørsholm, Denmark) and gentle stirring for $30 \mathrm{~s}$. Rennet-induced gelation was carried out for 7 min at $32^{\circ} \mathrm{C}$ and rennet-induced CN micelle sizes were determined at $32^{\circ} \mathrm{C}$ after 1,3 , and 7 min gel formation; the addition of chymosin corresponded to time zero. 


\section{$\zeta$-Potential}

The electrophoretic mobilities, and hence the calculated $\zeta$-potentials, were determined at $25^{\circ} \mathrm{C}$ on skim milks diluted 1:1,000 in SMUF with a ZetaSizer 3000HS apparatus (Malvern Instruments Ltd.). The measurement interval was set to -50 to $+10 \mathrm{mV}$. To avoid the interference of dust during the measurements, the SMUF solution was filtered through a $0.2-\mu \mathrm{m}$ filter (Pall Corporation) and the diluted samples were filtered through a $0.45-\mu \mathrm{m}$ filter (Pall Corporation). Five measurements were made on each sample.

\section{Rheological Measurements}

Rennet-induced gelation was performed according to Glantz et al. (2009) on skim milks using chymosin (0.90 $\mathrm{mL} / \mathrm{L}$ Chy-Max Plus, 200 international milk clotting units $/ \mathrm{mL}$, Christian Hansen A/S) in a Stresstech rheometer (ReoLogica Instruments AB, Lund, Sweden). After $30 \mathrm{~min}$ of gel formation, frequency sweeps varying from 0.01 to $1 \mathrm{~Hz}$ with a controlled strain at 0.01 were run. The elastic or storage modulus, $\mathbf{G}^{\prime}$, where $\mathrm{G}^{\prime}=\sigma_{0} / \gamma_{0} \times \cos \delta$, and the viscous or loss modulus, $\mathbf{G}^{\prime \prime}$, where $\mathrm{G}^{\prime \prime}=\sigma_{0} / \gamma_{0} \times \sin \delta\left(\sigma_{0}=\right.$ maximum stress; $\gamma_{0}=$ maximum shear strain; $\delta=$ phase angle, or phase difference between the strain and stress) were recorded. All samples were analyzed at least in duplicate.

\section{Milk Composition and Gelation Characteristics}

To obtain correlations between technological properties and milk composition traits, earlier published data on gel strength $\left(\mathrm{G}^{\prime}\right)$, gelation time, milk $\mathrm{pH}$, and the contents of protein, $\mathrm{CN}$, lactose, $\mathrm{Ca}, \mathrm{Mg}$, and $\mathrm{K}$ for the milk samples were used (Glantz et al., 2009). Rennetinduced gelation was carried out with low-amplitude oscillation measurements, the contents of protein and CN were analyzed by using the Kjeldahl method, the lactose content was determined by using an infrared technique, and the contents of $\mathrm{Ca}, \mathrm{Mg}$, and $\mathrm{K}$ were analyzed with inductively coupled plasma mass spectroscopy, all according to Glantz et al. (2009).

\section{Statistical Analyses}

Statistical ANOVA was used to determine unadjusted means and standard deviations. Estimates of the difference in herd and seasonal variations based on winter and summer milk samples were performed with 2 -sample $t$-tests. The Pearson correlation coefficient was calculated to estimate linear correlations. The level of significance was set at $P<0.05$. The general linear model was used to exclude differences caused by sampling day and analytical replicates. The statistical model used contained the fixed effects of herd, sampling day, and analytical replicate. Statistical analyses were performed using Minitab (version 14, Minitab Ltd., Coventry, UK).

\section{RESULTS AND DISCUSSION}

\section{Milk Selection}

Milk from elite dairy cows with a high genetic merit is analyzed and compared with milk from cows at normal farms in order to evaluate genetic progress in relation to different traits for the elite cows as a correlated response to selection for the Swedish breeding objective. This provides knowledge on the effects of animal selection on various milk traits, thus making it possible to include or exclude traits in the breeding objectives when optimizing for a certain milk composition or processing characteristic.

\section{Characteristics of Rennet-Induced Gelation}

Glantz et al. (2009) found genetic progress in relation to gelation characteristics for the elite dairy cows, with distinct progress for summer milk samples. Research herd summer milk samples had higher gel strength $(P=0.000-0.011)$ and shorter gelation time $(P=$ 0.004-0.038) when compared with summer milk from the other herds and reference (Table 1). When comparing summer milk from research herd SR and research herd SH with SR herd and SH herd summer milk, respectively, the different breeds in the research herd also showed higher gel strength $(\mathrm{P}=0.000$ and 0.022 , respectively) and shorter gelation time $(\mathrm{P}=0.004$ and 0.030, respectively). Furthermore, the results showed that there was no difference between the breeds in the research herd regarding both the gel strength and gelation time, whereas a difference could be seen when comparing the SR herd and the SH herd (gel strength, $P=0.000$; gelation time, $P=0.006$ ). This may indicate that breeding strategies of today have reduced the differences in gelation characteristics between the 2 breeds, thus reducing processability problems in the manufacture of cheese.

The different breeds in the research herd showed higher gel strengths for summer milk compared with the research herd in summer, which represents an average for the herd (Table 1). In the current study, research herd milk was sampled from a bulk tank containing milk from 2 milkings, whereas the sampling from the different breeds in the research herd was made during 1 milking to enable the separation of milk from the 2 breeds. Studies have shown a difference in milk yield 
Table 1. Unadjusted means (SD) for native $\mathrm{CN}$ micelle size $(\mathrm{df}=5)$, gel strength $\left[\mathrm{G}^{\prime}(30 \mathrm{~min})\right.$; $\left.\mathrm{df}=3\right]$, gelation time $(\mathrm{df}=3)$, and $\zeta$-potential $(\mathrm{df}=9)$ in winter and summer milk samples from the research herd, the Swedish Red (SR) herd, the Swedish Holstein (SH) herd, and reference milk ${ }^{1}$

\begin{tabular}{lcccc}
\hline Item & $\begin{array}{c}\text { Native CN micelle } \\
\text { size }(\mathrm{nm})\end{array}$ & $\begin{array}{c}\text { Gel strength } \\
{\left[\mathrm{G}^{\prime}(30 \mathrm{~min})\right](\mathrm{Pa})}\end{array}$ & $\begin{array}{c}\text { Gelation time } \\
(\mathrm{min})\end{array}$ & $\begin{array}{c}\text { S-Potential } \\
(\mathrm{mV})\end{array}$ \\
\hline Winter & & & & \\
$\quad$ Research herd & $204(14)$ & $44(6)$ & $8.3(0.9)$ & $-19.5(1.1)$ \\
SR herd & $197^{2}(22)$ & $10^{* * *}(8)$ & $15.7^{* *}(3.2)$ & $-18.9^{2}(1.0)$ \\
SH herd & $200^{2}(18)$ & $37^{2}(7)$ & $8.3^{2}(1.0)$ & $-19.4^{2}(1.1)$ \\
Reference milk & $201^{2}(2)$ & $39^{2}(9)$ & $8.4^{2}(0.9)$ & $-19.7^{2}(1.0)$ \\
Summer & & & & \\
Research herd & $179(3)$ & $46(6)$ & $7.1(0.9)$ & $-19.7^{2}(0.8)$ \\
SR herd & $191^{* * *}(5)$ & $3^{* * *}(3)$ & $25.0^{* *}(6.6)$ & $-19.4^{2}(0.7)$ \\
SH herd & $200^{* *}(14)$ & $22^{* *}(4)$ & $9.2^{*}(1.3)$ & $-18.5^{2}(1.6)$ \\
Reference milk & $199^{* * *}(5)$ & $59^{2}(10)$ & $10.4^{*}(1.9)$ & $-18.8^{*}(0.8)$ \\
Research herd SR & $178^{2}(2)$ & $63^{2}(19)$ & $7.1^{2}(1.1)$ & $-19.8^{2}(1.3)$ \\
Research herd SH & $183^{*}(3)$ & $4.5^{2}(2.6)$ & $-19.1^{2}(1.1)$ \\
\hline
\end{tabular}

${ }^{1}$ Values are also given for summer milk samples from the research herd SR and research herd SH. $P$-values are for differences between the research herd and SR herd, SH herd, reference milk, research herd SR, and research herd $\mathrm{SH}$ in winter and summer milk samples.

${ }^{2}$ Value is not significant.

${ }^{*} P<0.05 ;{ }^{* *} P<0.01 ;{ }^{* * *} P<0.001$.

and milk composition between morning and evening milk samples (Gilbert et al., 1973; Quist et al., 2008), which could explain the obtained results.

$\zeta$-Potential can be used as an indicator of charge interactions and can be related to the stability of colloidal dispersions. Colloids with a high absolute $\zeta$-potential value are electrically stabilized, whereas colloids with a low absolute value tend to flocculate (Walstra and Jenness, 1984). The obtained $\zeta$-potentials of CN micelles in winter and summer skim milk samples from the different herds and reference, with $\mathrm{pH}$ varying between 6.67 and 6.73 in these samples, are summarized in Table 1 . No difference was seen for winter milk samples when comparing research herd milk with reference milk, whereas a lower $\zeta$-potential was observed for research herd milk during summer compared with reference summer milk $(P=0.034)$. Neither was any seasonal difference observed for any of the herds or reference. The values of -19 to $-20 \mathrm{mV}$ obtained in this study are in the range found previously for $\mathrm{CN}$ micelles at normal milk $\mathrm{pH}$ (Anema and Klostermeyer, 1996; Famelart et al., 2003; Philippe et al., 2005). However, it should be noted that different diluents as well as measurement techniques greatly influence the results obtained and should thus be considered when comparing reported results. The diluent used in the present study was SMUF, but by using milk ultrafiltrate prepared from the same milk, structural properties of the sample may be retained. The choice of diluent could have affected the obtained results.

The elastic $\left(G^{\prime}\right)$ and viscous $\left(G^{\prime \prime}\right)$ moduli as a function of frequency after 30 min of gel formation are shown in Figure 1. As can be derived from Figure 1, an increased frequency showed stronger gels for all the herds and reference. For the viscous modulus, on the other hand, the viscous behavior increased at low frequencies, whereas it was constant at higher frequencies as the viscous properties were stabilized. The amplitudes of the moduli were shown to be different between the samples. This can be explained by the different gel strengths obtained after 30 min of gel formation. Poorly coagulating milk from the SR herd tended to be more frequency-dependent at low frequencies, which once again demonstrate the weaker gels formed.

\section{Native CN Micelle Size and the Importance of Milk Composition on the Micellar Size}

The native CN micelle size in summer milk from the research herd was smaller than in summer milk from the reference $(P=0.000)$, whereas no difference was observed in winter milk (Table 1). Furthermore, research herd milk showed seasonal variation $(P=0.007)$, which could not be seen for the other herds or reference, and the native $\mathrm{CN}$ micelle size of research herd milk varied between $204 \mathrm{~nm}$ (SD 14) in winter and $179 \mathrm{~nm}$ (SD 3) in summer. This seasonal trend has been observed earlier in bulk milk and milk of individual cows (Holt and Baird, 1978; Holt and Muir, 1978; Devold, 2004). Also, the different breeds in the research herd had smaller native CN micelles when comparing summer milk from the research herd SR and research herd SH with summer milk from the SR herd and SH herd $(P=0.000$ and 0.014 , respectively). This indicates that a smaller 
native micellar size may favor gelation characteristics of research herd milk and that genetic progress in relation to $\mathrm{CN}$ micelle size was found for the elite dairy cows as a correlated response to selection for the Swedish breeding objective if optimizing for gelation characteristics. The results obtained in this study on the native CN micelle size are in the range found previously for dairy milk and milk of individual cows (Holt and Muir, 1978; Devold et al., 2000).

Components of the protein profile, such as amounts of total protein and $\mathrm{CN}$, as well as lipid, carbohydrate, and mineral profiles were analyzed for correlations with the size of native $\mathrm{CN}$ micelles (Table 2). Results are shown only for components correlated significantly $(P$ $<0.05)$ with the native micellar size. As can be derived from Table 2 , the size of native $\mathrm{CN}$ micelles was influenced by milk $\mathrm{pH}(P=0.020)$ and the contents of $\mathrm{Mg}(P=0.014)$ and $\mathrm{K}(P=0.016)$. Milk $\mathrm{pH}$ correlated positively with native micellar size, implying that a lower milk $\mathrm{pH}$ would result in smaller native $\mathrm{CN}$ micelles, whereas a negative correlation was observed between native $\mathrm{CN}$ micelle size and $\mathrm{Mg}$ and $\mathrm{K}$. None of the components of the protein fraction examined significantly influenced the native micellar size, which is in contrast to results found previously in individual cows (Devold et al., 2000). Neither was any correlation found with the total $\mathrm{Ca}$ content, which is in agreement with previous studies on bulk tank milk and milk from individual cows (Dalgleish et al., 1989; Devold et al., 2000). However, because the elite dairy cows showed genetic progress in relation to both milk gelation and native CN micelle size as a correlated response to selection for the Swedish breeding objective, it could be of interest to examine whether soluble $\mathrm{Ca}^{2+}$ naturally occurring in milk affects any of these traits when studying milk from elite dairy cows.

\section{Importance of Analyzed Milk Traits on Rennet-Induced Gelation}

As for the native CN micelle size, components of the protein, lipid, and carbohydrate profiles as well as minerals were analyzed for correlations with gel strength, gelation time, and $\zeta$-potential to study the effects of milk traits on gelation characteristics (Table 2). Gel strength was shown to correlate with gelation time $(P$ $=0.000)$, milk $\mathrm{pH}(P=0.005)$, and protein $(P=0.027)$ and lactose $(P=0.041)$ contents, whereas the contents of protein $(P=0.021), \mathrm{CN}(P=0.028)$, and lactose $(P=0.033)$ had effects on gelation time. No correlation was found for the $\zeta$-potential with any of the studied traits. The strong correlation found between gel strength and gelation time has been reported earlier on
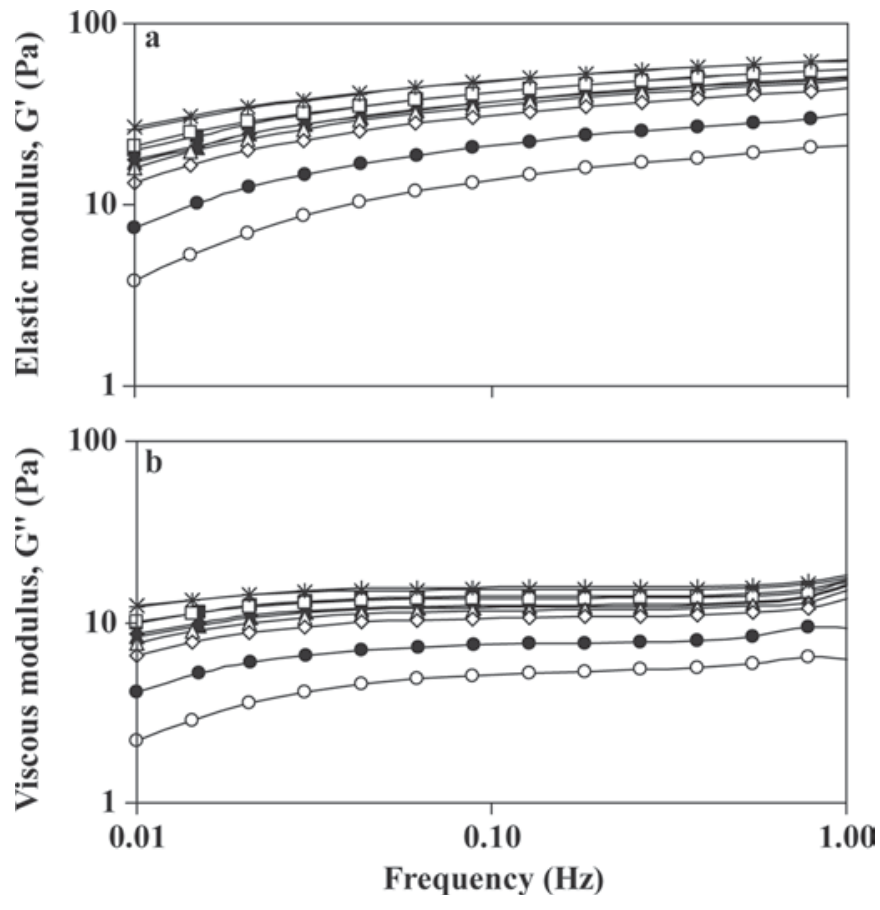

Figure 1. Frequency sweep with a) elastic $\left(\mathrm{G}^{\prime}\right)$ and $\left.\mathrm{b}\right)$ viscous $\left(\mathrm{G}^{\prime \prime}\right)$ moduli after $30 \mathrm{~min}$ of rennet-induced gel formation in winter milk

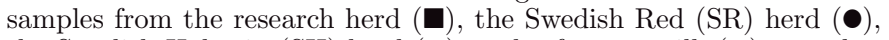
the Swedish Holstein $(\mathrm{SH})$ herd $(\mathbf{\Lambda})$, and reference milk $(\bullet)$, together with results from summer milk samples from the research herd $(\square)$, the SR herd $(O)$, the SH herd $(\Delta)$, reference milk $(\diamond)$, the research herd SR $(+)$, and the research herd SH $(\times ; \mathrm{df}=3)$.

individual cows (Ikonen et al., 2004; Hallén et al., 2007) and was expected because these traits describe the consecutive stages in the gelation process. A negative effect of the protein content was found on gel strength, whereas the protein content had positive effect on gelation time. Similar results have been reported by Ikonen et al. (1999). Also, Pagnacco and Caroli (1987) and Ikonen et al. (2004) have noted a positive correlation between low protein content and short gelation time. In contrast, other studies have indicated that high protein content improves gel strength (Pagnacco and Caroli, 1987; Auldist et al., 2004; Hallén et al., 2007) and shortens gelation time (Lindström et al., 1984). Hence, the correlation between protein content and gelation characteristics seems to be contradictory. Selecting for high protein content through breeding may thus result in uncertainties regarding milk gelation characteristics. Higher lactose content was found to enhance gelation properties, which is in agreement with results reported previously (Amenu and Deeth, 2007). However, the synthesis of lactose is an energy-demanding process and selecting for both higher lactose content and milk yield at the same time thus results in increased energy loss for the cows. 
Table 2. The Pearson correlation coefficient between native CN micelle size, gel strength, gelation time, $\zeta$-potential, and milk parameters, measured on winter and summer milk samples of the research herd, the Swedish Red (SR) herd, the Swedish Holstein (SH) herd, reference milk, the research herd SR, and the research herd $\mathrm{SH}(\mathrm{df}=9)^{1}$

\begin{tabular}{|c|c|c|c|c|}
\hline Milk trait & Native CN micelle size & Gel strength & Gelation time & $\zeta$-Potential \\
\hline Gel strength & $-0.45^{2}$ & & & \\
\hline Gelation time & $0.16^{2}$ & $-0.90 * * *$ & & \\
\hline$\zeta$-Potential & $0.40^{2}$ & $-0.36^{2}$ & $0.13^{2}$ & \\
\hline $\mathrm{pH}$ & $0.72 *$ & $-0.80^{* *}$ & $0.57^{2}$ & $0.30^{2}$ \\
\hline Protein & $0.51^{2}$ & $-0.69^{*}$ & $0.71^{*}$ & $-0.01^{2}$ \\
\hline $\mathrm{CN}$ & $0.23^{2}$ & $-0.63^{2}$ & $0.69^{*}$ & $-0.36^{2}$ \\
\hline $\mathrm{Mg}$ & $-0.74^{*}$ & $0.11^{2}$ & $0.14^{2}$ & $-0.18^{2}$ \\
\hline $\mathrm{K}$ & $-0.73^{*}$ & $0.24^{2}$ & $-0.01^{2}$ & $0.10^{2}$ \\
\hline Lactose & $-0.17^{2}$ & $0.65^{*}$ & $-0.67^{*}$ & $0.17^{2}$ \\
\hline
\end{tabular}

${ }^{1}$ Results are shown only for components correlated significantly $(P<0.05)$ with at least 1 trait.

${ }^{2}$ Value is not significant.

${ }^{*} P<0.05 ;{ }^{*} P<0.01 ; * * * P<0.001$

The correlations found between milk traits and rennet-induced gelation are based on data from all the studied herds and reference. However, SR herd milk tended to coagulate poorly in both winter and summer, in contrast to the other herds and reference that had well-coagulating milk throughout the year (Table $1)$. When data from the SR herd were excluded from the correlation analysis, a negative effect of native $\mathrm{CN}$ micelle size on gel strength was found $(P=0.029)$. This indicates that smaller native micelles form stronger gels for well-coagulating milk, which has been reported earlier (Amenu and Deeth, 2007). One explanation for this could be, for same unit quantity of $\mathrm{CN}$, that smaller particles present much larger surface area for reaction, thereby forming firmer gels. No correlation was found between native $\mathrm{CN}$ micelle size and gelation time. Furthermore, a lower milk $\mathrm{pH}$ increases gel strength $(P$ $=0.002)$, shortens gelation time $(P=0.006)$, and decreases the size of native $\mathrm{CN}$ micelles $(P=0.023)$. This effect on milk gelation was not seen by Wedholm et al. (2006) when studying milk from individual cows, but was expected because of an increased rennet activity at lower pH (Lucey, 2002). Lowering milk pH through selective breeding would thus enhance gelation characteristics for well-coagulating milk and also decrease native CN micelle size, which would further contribute to a firmer gel network. Thus, it is important to monitor milk traits for genetic selection programs. Studies have reported that poorly coagulating or noncoagulating milk samples are associated with the concentration of $\kappa-\mathrm{CN}$ and $\mathrm{pH}, \mathrm{SCC}$, and protein contents of milk (Tyrisevä et al., 2003; Ikonen et al., 2004; Wedholm et al., 2006). Selecting for traits that result in poorly coagulating or noncoagulating milk would be an economical disadvantage to the dairy industry. Nevertheless, it is essential to understand which parameters and mechanisms are responsible for poorly coagulating or noncoagulating milk to be able to improve gelation characteristics of these milks and thus increase the economical output of both the dairy and breeding industries.

\section{Rennet-Induced CN Micelle Size}

Rennet-induced CN micelle size and aggregation was followed with light scattering and rheological measurements during the initial stage of gel formation on winter and summer milk samples from the research herd and SR herd (Figure 2). These herds were chosen based on the results of rennet-induced gelation (Table 1), with the research herd having well-coagulating milk but the SR herd having poorly coagulating milk. As can be seen by light scattering in Figure 2, the rennetinduced micellar size initially decreased as chymosin was added, which probably can be explained by the action of chymosin that cleaves off the glycomacropeptide from $\kappa-\mathrm{CN}$ located at the surface of the micelles. The same initial decrease has been found previously (Walstra et al., 1981; Holt and Dalgleish, 1986). The rennet-induced $\mathrm{CN}$ micelle size then increased again because of aggregation of the micelles for both wellcoagulating and poorly coagulating milk. Rheological measurements indicate the time at which gelation begins as a result of an increase in $\mathrm{CN}$ micelle size (Figure 2 ). This shows that light scattering is able to indicate a change in $\mathrm{CN}$ micelle size almost directly after addition of chymosin, which cannot be registered with rheological measurements.

\section{CONCLUSIONS}

The results of this study showed enhanced gelation characteristics and genetic progress in relation to $\mathrm{CN}$ micelle size for elite dairy cows as a correlated response to selection for the Swedish breeding objective if opti- 


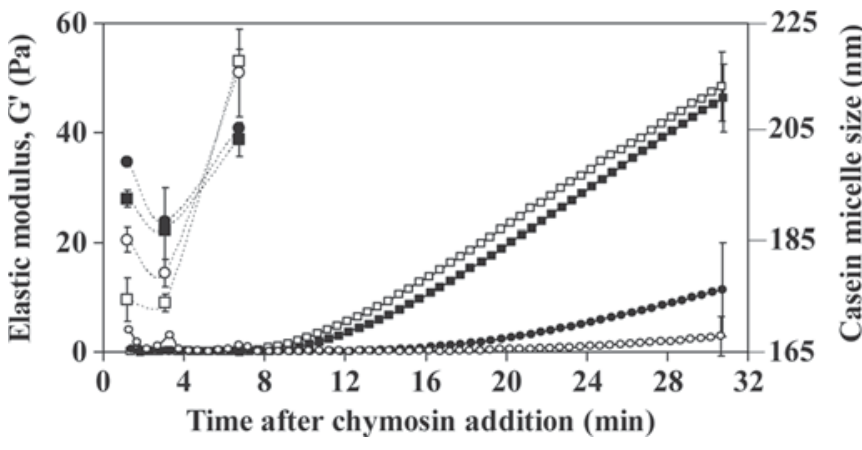

Figure 2. Casein micelle size (dotted lines; $\mathrm{df}=1$ ) and gel strength determined as gel elasticity (elastic modulus, $\mathrm{G}^{\prime}$; solid lines; $\mathrm{df}=3$ ) as a function of time after addition of chymosin in winter milk samples from the research herd $(\boldsymbol{\square})$ and the Swedish Red (SR) herd $(\bullet)$, together with results from summer milk samples from the research herd $(\square)$ and the SR herd (O).

mizing for milk gelation characteristics. Milk $\mathrm{pH}$ and protein, CN, and lactose contents were found to affect milk gelation. Smaller native CN micelles were shown to form stronger gels when poorly coagulating milk was excluded from the analysis. Furthermore, milk $\mathrm{pH}, \mathrm{Mg}$, and $\mathrm{K}$ had effects on the size of native $\mathrm{CN}$ micelles. This may imply that selection for smaller native CN micelles and lower milk $\mathrm{pH}$ through breeding would enhance gelation properties and may thus optimize the initial step in the processing of cheese. Further studies are needed to obtain specific information on the genes that are associated with these traits in order to adjust breeding practices.

\section{ACKNOWLEDGMENTS}

This work was supported by grants from the Swedish Farmer's Foundation for Agricultural Research (SLF), Stockholm, Sweden.

\section{REFERENCES}

Amenu, B., and H. C. Deeth. 2007. The impact of milk composition on cheddar cheese manufacture. Aust. J. Dairy Technol. 62:171184 .

Anema, S. G., and H. Klostermeyer. 1996. Zeta-potentials of casein micelles from reconstituted skim milk heated at 120 degrees celcius. Int. Dairy J. 6:673-687.

Auldist, M. J., K. A. Johnston, N. J. White, W. P. Fitzsimons, and M. J. Boland. 2004. A comparison of the composition, coagulation characteristics and cheesemaking capacity of milk from Friesian and Jersey dairy cows. J. Dairy Res. 71:51-57.

Dalgleish, D. G. 1992. The enzymatic coagulation of milk. Pages 579619 in Advanced Dairy Chemistry. Vol. 1: Proteins. 1st ed. P. F. Fox, ed. Elsevier Science Publishers Ltd., London, UK.

Dalgleish, D. G. 1998. Casein micelle as colloids: Surface structures and stabilities. J. Dairy Sci. 81:3013-3018.

Dalgleish, D. G., J. Brinkhuis, and T. J. Payens. 1981. The coagulation of differently sized casein micelles by rennet. Eur. J. Biochem. 119:257-261
Dalgleish, D. G., D. S. Horne, and A. J. R. Law. 1989. Size-related differences in bovine casein micelles. Biochim. Biophys. Acta 991:383-387.

Dalgleish, D. G., P. A. Spagnuolo, and H. D. Goff. 2004. A possible structure of the casein micelle based on high-resolution fieldemission scanning electron microscopy. Int. Dairy J. 14:10251031.

de Kruif, C. G. 1998. Supra-aggregates of casein micelles as a prelude to coagulation. J. Dairy Sci. 81:3019-3028.

de Kruif, C. G. 1999. Casein micelle interactions. Int. Dairy J. 9:183188.

Devold, T. G. 2004. Effect of milk protein polymorphism on protein composition in milk from Norwegian breed of dairy goat and Norwegian dairy cattle. PhD Thesis. Agricultural University of Norway, Aas, Norway.

Devold, T. G., M. J. Brovold, T. Langsrud, and G. E. Vegarud. 2000. Size of native and heated casein micelles, content of protein and minerals in milk from Norwegian Red cattle - Effect of milk protein polymorphism and different feeding regimens. Int. Dairy J. $10: 313-323$.

Ekstrand, B., M. Larsson-Raznikiewicz, and C. Perlmann. 1980. Casein micelle size and composition related to the enzymatic coagulation process. Biochim. Biophys. Acta 630:361-366.

Famelart, M.-H., J. Tomazewski, M. Piot, and S. Pezennec. 2003 Comparison of rheological properties of acid gels made from heated casein combined with beta-lactoglobulin or egg ovalbumin. Int. Dairy J. 13:123-134.

Ford, G. D., and A. S. Grandison. 1986. Effect of size of casein micelles on coagulation properties of skim milk. J. Dairy Res. 53:129133.

Fox, P. F., and A. Brodkorb. 2008. The casein micelle: Historical aspects, current concepts and significance. Int. Dairy J. 18:677684.

Gilbert, G. R., G. L. Hargrove, and M. Kroger. 1973. Diurnal variations in milk yield, fat yield, milk fat percentage, and milk protein percentage of Holstein-Friesian cows. J. Dairy Sci. 56:409-410.

Glantz, M., H. Lindmark Månsson, H. Stålhammar, L.-O. Bårström, M. Fröjelin, A. Knutsson, C. Teluk, and M. Paulsson. 2009. Effects of animal selection on milk composition and processability. J. Dairy Sci. 92:4589-4603.

Hallén, E., T. Allmere, J. Näslund, A. Andrén, and A. Lundén. 2007. Effect of genetic polymophism of milk proteins on rheology of chymosin-induced milk gels. Int. Dairy J. 17:791-799.

Holt, C., and L. Baird. 1978. Natural variations in average size of bovine casein micelles. 1. Milks from individual Ayrshire cows. J. Dairy Res. 45:339-345.

Holt, C., and D. G. Dalgleish. 1986. Electrophoretic and hydrodynamic properties of bovine casein micelles interpreted in terms of particles with an outer hairy layer. J. Colloid Interface Sci. 114:513-524.

Holt, C., C. G. de Kruif, R. Tuinier, and P. A. Timmins. 2003. Substructure of bovine micelles by small-angle X-ray and neutron scattering. Colloids Surf. A Physicochem. Eng. Asp. 213:275284.

Holt, C., and D. D. Muir. 1978. Natural variations in the average size of bovine casein micelles. II. Milk samples from creamery bulk silos in south west Scotland. J. Dairy Res. 45:347-353.

Horne, D. S. 1998. Casein interactions: Casting light on the black boxes, the structure in dairy products. Int. Dairy J. 8:171-177.

Ikonen, T., K. Ahlfors, R. Kempe, M. Ojala, and O. Ruottinen. 1999. Genetic parameters for the milk coagulation properties and prevalence of noncoagulating milk in Finnish dairy cows. J. Dairy Sci. 82:205-214.

Ikonen, T., S. Morri, A.-M. Tyrisevä, O. Ruottinen, and M. Ojala. 2004. Genetic and phenotypic correlations between milk coagulation properties, milk production traits, somatic cell count, casein content, and pH of milk. J. Dairy Sci. 87:458-467.

Interbull. 2009. Genetic evaluation. Production. http://www.interbull org/eval/framesida-prod.htm Accessed Aug. 24, 2009.

International Dairy Federation. 2008. The world dairy situation 2008. Bulletin 432/2008. IDF, Brussels, Belgium. 
Jenness, R., and J. Koops. 1962. Preparation and properties of a salt solution which simulates milk ultrafiltrate. Neth. Milk Dairy J. $16: 153-164$.

Lindström, U. B., V. Antila, and J. Syväjärvi. 1984. A note on some genetic and non-genetic factors affecting clotting time of Ayrshire milk. Acta Agric. Scand. 34:349-355.

Lodes, A., I. Krause, J. Buchberger, J. Aumann, and H. Klostermeyer. 1996. The influence of genetic variants of milk proteins on the compositional and technological properties of milk. 1. Casein micelle size and the content of non-glycosylated kappa-casein. Milchwissenschaft 51:368-373.

Lucey, J. A. 2002. Formation and physical properties of milk protein gels. J. Dairy Sci. 85:281-294.

Lucey, J. A., M. E. Johnson, and D. S. Horne. 2003. Perspectives on the basis of the rheology and texture properties of cheese. J. Dairy Sci. 86:2725-2743.

Lucey, J. A., and H. Singh. 1998. Formation and physical properties of acid milk gels: A review. Food Res. Int. 30:529-542.

Niki, R., and S. Arima. 1984. Effects of size of casein micelles on firmness of rennet curd. Jpn. J. Zootech. Sci. 55:409-415.

Pagnacco, G., and A. Caroli. 1987. Effect of casein and betalactoglobulin genotypes on renneting properties of milks. J. Dairy Res. 54:479-485.

Philippe, M., Y. Graët, and F. Gaucheron. 2005. The effects of different cations on the physiochemical characteristics of casein micelles. Food Chem. 90:673-683.

Quist, M. A., S. J. LeBlanc, K. J. Hand, D. Lazenby, F. Miglior, and D. F. Kelton. 2008. Milking-to-milking variability for milk yield, fat and protein percentage, and somatic cell count. J. Dairy Sci. 91:3412-3423.

Swedish Dairy Association. 2008. Dairy Statistics. Swedish Dairy Association, Stockholm, Sweden.

Tuinier, R., and C. G. de Kruif. 2002. Stability of casein micelles in milk. J. Chem. Phys. 117:1290-1295.

Tyrisevä, A.-M., T. Ikonen, and M. Ojala. 2003. Repeatability estimates for milk coagulation traits and non-coagulation of milk in Finnish Ayrshire cows. J. Dairy Res. 70:91-98.

VikingGenetics. 2008. Avelsvärdering. Version VIII. VikingGenetics, Skara, Sweden.

Walsh, C. D., T. P. Guinee, W. D. Reville, D. Harrington, J. J. Murphy, B. T. O'Kennedy, and R. J. FitzGerald. 1998. Influence of kappa-casein genetic variant on rennet gel microstructure, cheddar cheesemaking properties and casein micelle size. Int. Dairy J. 8:707-714.

Walstra, P. 1999. Casein sub-micelles: Do they exist? Int. Dairy J. 9:189-192.

Walstra, P., V. A. Bloomfield, G. J. Wei, and R. Jenness. 1981. Effect of chymosin action on the hydrodynamic diameter of casein micelles. Biochim. Biophys. Acta 669:258-259.

Walstra, P., and R. Jenness. 1984. Dairy Chemistry and Physics. John Wiley \& Sons Inc., Hoboken, NJ.

Wedholm, A., L. B. Larsen, H. Lindmark Månsson, A. H. Karlsson, and A. Andrén. 2006. Effect of protein composition and the cheesemaking properties of milk from individual dairy cows. J. Dairy Sci. 89:3296-3305. 